It turns out that expert support of legislative activity and legislative process as a whole becomes the most important mechanism for preventing gaps in the system of legislation, avoiding legal conflicts, eliminating defects, legislative abnormalities and erroneous norms, combating corruption, etc. This is essential in anti-discrimination processes. According to foreign experience, expert activity plays a huge role in terms of the effectiveness of the legislative process. High activity and participation of civil society institutions in the implementation of anti-discrimination expertise, especially academics, independent experts, media representatives, NGOs, various associations of human rights activists, etc. are noted.

It is concluded that the constitutional and legal regulation of expert support of the legislative process in the field of combating discrimination in Ukraine is insufficient. It is proved that the facultative nature of the results of scientific legal expertise leads to a decrease in the role and weight of legal science in the process of creating legal norms. Indeed, despite some contradictions and fragmentation, the domestic doctrine in the field of countering discrimination far outstrips the development of anti-discrimination legislation. It seems that this is one of the reasons for the poor quality and inefficiency of some of the laws. The participation of lawyers in the early stages of the lawmaking procedure is one of the important guarantees of the quality and preconditions for anti-discrimination legislation.

Key words: legislation, legislative activity, expert activity, discrimination, human rights, equality.

DOI: 10.33.66.3/2524-017X-2019-10-34-41

УДК 343.22

Роман Вікторович Вереша, доктор юридичних наук, професор,професор кафедри кримінального та адміністративного права Академії адвокатури України

\title{
ОСНОВНІ ФЕНОМЕНОЛОГІЧНІ АСПЕКТИ МЕТИ ЗЛОЧИНУ
}

Постановка проблеми. Мета злочину є явищем психологічним, питання його аналізу та вивчення мають вирішуватись на пов'язаних з психологією та кримінологією рівнях, що матиме вплив на результати пізнання, отримані в межах однієї науки, на постановку пізнавальних завдань і уточнень елементів понять про свій предмет в іншій науці. Проблема мети вчинення злочину традиційно належить до однієї з ключових у кримінальній науці. Проте в наукових публікаціях існує певна невизначеність та дискусійність у підходах до розуміння сутності мети вчинення злочину, iї відмежування від такої категорії, як мотив злочину. В кримінальному праві зарубіжних держав не вирішено питання, чи слід обов' язково відносити мету вчинення злочину до суб'єктивної сторони злочину і чи слід досліджувати мету злочину при розслідуванні злочинів. Через відсутність єдиного наукового підходу до зазначеної проблематики виникають труднощі при кваліфікації злочинів.

Аналіз останніх досліджень та публікацій. Загальновизнаним вважається, що мета вчинення злочину - це уявлення особи про кінцевий результат своєї діяльності, те, чого особа прагне досягти, вчиняючи злочин. Як зазначає I. О. Харь «мета (перспектива) - джерело спрямованості суб'єкта, його активності. Вона відображає уявну модель майбутнього (чого б хотіла досягнути особа в результаті своїх дій). При цьому, в кожному конкретному випадку може бути не одна мета дії, але певна з них все ж домінує» [1, c.107]. Мета злочину опосередковує засоби і характер дій злочинця, визначає напрямок його дій $[2$, с. 83$]$.

Мета злочину - це той кінцевий (проміжний) результат, що міститься у свідомості винного, до якого він прагне, скоюючи злочин [3, с. 45]. Мета вчинення злочину являє собою психічне уявлення суб'єкта про результат, до якого він прагне [4, с. 113]. «Особа діє з метою вчинити злочин, якщо вона знає, що робить, і прагне до досягнення природних і ймовірних наслідків такої поведінки, які, як відомо, є результатом такої поведінки» [5, с. 179].

Доповнюючи вищенаведені позиції, С. Персонс стверджує, що мета злочину має місце, коли особа бажає настання наслідків своїх дій, або коли особа не хоче настання наслідків, але вчиняє дію, прекрасно розуміючи їі ймовірні наслідки [6, с. 7]. 
У юридичній літературі, присвяченій аналізу мети злочину, підкреслюється, що мета є обов'язковою умовою злочину з прямим умислом, адже це відображає психічне ставлення особи не лише до діяння, а й наслідків такого діяння. Існують також думки, що кримінально караним $є$ не будь-яке порушення вимог, а лише те, яке вчиняється з метою отримання неправомірної вигоди, оскільки така мета дозволяє відмежувати злочинне діяння від незлочинного [7, с. 123].

У теорії кримінального права мету злочину розглядають паралельно 3 мотивом злочину, що дещо зменшує самостійність мети. Результатом цього стає явно недостатня увага до вивчення мети, як самостійної ознаки злочину. Так, на думку Л. О. Семикіна, мотив і мета - поняття тісно пов'язані, взаємообумовлені, корелятивні. Мета завжди опосередкована мотивом, так само, як мотив опосередкований метою. Від мотиву залежить, як людина формулює мету, яким способом вона буде здійснена [8, с. 115]. «Мета злочину виникає на грунті злочинного мотиву, і разом вони утворюють ту основу, на якій народжується вина» [9, с. 147].

При цьому варто зазначити, що в кримінальному праві Англії та США вина визначається терміном «mens rea». Англомовні автори передають зміст терміна «mens rea» англійською мовою використовуючи переважно вираз «guilty mind», що являє більш точний переклад останнього вже на українську мову і звучить як «винний розум», хоча при цьому не виключається і такий варіант, як «винна думка» [10, с. 114].

В свою чергу, кримінальне право Англії та США вживають два близьких поняття - «intent, intention» (мета) i «motive» (мотив). У повсякденному вживанні терміни «мотив» $\mathrm{i}$ «мета»використовуються як синонімами, але в праві вони розрізняються. Мотив призводить до постановки мети. Він передує злочинній поведінці, тоді як мета супроводжує іiі. Мотив спрямовує розум вчинити злочин - спонукає вчинити дію, щоб досягти певного результату.

Мета статті полягає в можливості використання отриманих результатів у правотворчому процесі щодо вдосконалення кримінального законодавства, норми якого містять мету злочину в якості ознаки суб'єктивної сторони складу злочину, при вирішенні питань диференціації кримінальної відповідальності і покарання за вчинення злочинів, склади яких передбачають мету злочину в якості кваліфікуючої обставини; у правозастосовчій діяльності при кваліфікації злочинів, склади яких передбачають мету злочину в якості обов'язкової ознаки. Актуальним є дослідження та обгрунтування необхідності встановлення мети вчинення злочину як факультативної ознаки суб'єктивної сторони злочину, що дозволить виявити реальні причини злочину та застосувати правильний вид та розмір покарання.

Положення діалектичного методу наукового пізнання соціально-правових явищ, його закони і категорії складають методологічну основу дослідження кримінально-правової характеристики мети вчинення злочину, в процесі якого послідовно використовувалися загальнонаукові методи дослідження: системний, історичний, логічний, функціональний та ін. У ході дослідження кримінально-правової характеристики мети вчинення злочину використовувалися також такі методи: спостереження (при дослідженні суб'єктивної сторони складу злочину); аналіз (при дослідженні кримінального законодавства України та іноземних держав, нормативних джерел регулювання та визначення суб'єктивної сторони складу злочину, кримінальних проваджень, літературних джерел, які висвітлюють досліджувану проблему); порівняння (при вивченні подібності та відмінності суб'єктивних ознак складу злочину); конкретно-соціологічний (при вивченні матеріалів судової практики та статистичних даних з даної проблеми).

Основні результати дослідження. Метою цього дослідження є дати кримінально-правову характеристику мети вчинення злочину. Дослідження мети злочину викликано нагальною потребою не лише правильно кваліфікувати злочини, а й визначити ступінь вини злочинця, призначити йому відповідне його вини покарання, або можливо, звільнити від кримінальної відповідальності чи відмовитися від кримінального переслідування. Крім того, мета злочину є суттєвою характеристикою злочинця, необхідною при вирішенні питання про можливість виправлення засудженого.

Правильний аналіз та встановлення мети злочину є дуже часто вирішальним для кваліфікації злочинів та постановленні вироків, оскільки при наявності всіх ознак злочину та його результату часто буває, що обвинувачена особа не бажала його скоювати. I тому етап дослідження та визначення, які конкретні злочинні наслідки своїх дій бажав та передбачав обвинувачений, можливе під час проведення детального аналізу злочину, з'ясування всіх його обставин. 
На сьогоднішній день, ані в законодавстві, ані в науковій літературі немає єдиного підходу до визначення поняття «мета злочину». В науці кримінального права суб'єктивну сторону злочину визначають як внутрішню сторону злочину, тобто психічну діяльність особи, що відображає ставлення її свідомості та волі до злочинного діяння, яке нею здійснюється, і до його наслідків.

Таким чином, суб'єктивна сторона не має матеріального або фізичного виразу. Вона може мати свій вираз лише на підсвідомому та психічному рівнях людини, що в свою чергу, проявляється у ставленні злочинця до суспільно небезпечного діяння та суспільно важливих інтересів, що ним порушуються, а також до наслідків такого діяння. Тобто суб'єктивна сторона складу злочину показує вольовий/невольовий, свідомий/несвідомий прояв психічного стану злочинця.

Враховуючи той факт, що суб'єктивна сторона злочину виступає обов'язковим елементом будьякого суспільно небезпечного діяння, що має склад злочину, ії встановлення полягає у з'ясуванні всіх ознак. У кримінальному праві виділяються дві форми умислу - прямий та непрямий. В першому випадку є усвідомлення особою суспільно небезпечного характеру свого діяння і бажання настання негативних наслідків, а в другому - усвідомлення суспільної небезпеки дії (або бездіяльності), передбачення настання можливих суспільно небезпечних наслідків, і хоча особа і не бажає, але свідомо припускає їх настання або ставилася до них байдуже. Вчинення злочину з необережності можливе у випадках злочинної самовпевненості (передбачення можливості настання суспільно небезпечних наслідків при легковажному розрахунку на їх відвернення) та злочинної недбалості (непередбачення можливості настання суспільно небезпечних наслідків діяння, при наявності такої можливості або такого обов'язку).

Враховуючи той факт, що мета злочину на сьогодні є необхідною лише у випадках, передбачених для окремих видів злочинів, можна зробити висновок, що мета злочину, по суті, $є$ необов'язковою, а факультативною ознакою суб'єктивної сторони злочину, за винятком чітко прописаних в законодавстві випадків ії наявності. Мета злочину є характерною для злочинів, що вчиняються з прямим умислом.

У Примірному Кримінальному кодексі Сполучених Штатів Америки містяться розгорнуті визначення форм вини. «З метою» і «свідомо» - форми умисної вини. Перша 3 них визначається таким чином: особа діє з метою відносно матеріального елементу посягання у випадках:

- якщо зазначений елемент містить у собі характер іiі поведінки або результат поведінки, його свідома мета полягає у здійсненні такої поведінки або в заподіянні такого результату;

- якщо зазначений елемент містить у собі супутні обставини, вона усвідомлює існування таких обставин або припускає чи сподівається на те, що вони існують.

Мета може бути не лише кінцевим результатом, до якого прагне особа, а й засобом для досягнення іншого результату [11, с. 51$]$.

Проведений аналіз дає можливість стверджувати, що в кримінальному праві зарубіжних держав спостерігається тенденція визначення мети не як обов'язкової ознаки злочинів. В залежності від наявності чи відсутності мети в злочинах з непрямим умислом, практика застосування кримінального права може відрізнятись на стадії кваліфікації злочину та при призначенні покарання.

Враховуючи той факт, що мета злочину є з самого початку явищем психологічним, питання iii аналізу та вивчення мають вирішуватись на пов'язаних з психологією та кримінологією рівнях, що матиме вплив на результати пізнання. Встановлення мети злочину, як однієї з ознак суб'єктивної сторони суспільно небезпечного діяння, дозволить виявити реальні причини злочину та застосувати правильний вид та розмір покарання.

Як правило, мета являє собою уявний результат, якого прагне досягти винуватий на момент вчинення злочину. Отже, під метою розуміється бажання особи, яка вчиняє суспільно небезпечне діяння, досягти шкідливого результату.

Висновки. Суб'єктивна сторона складу злочину показує вольовий/невольовий, свідомий/несвідомий прояв психічного стану злочинця. Суб'єктивна сторона злочину виступає обов'язковим елементом будь-якого суспільно небезпечного діяння, що містить склад злочину. При дослідженні злочину, до факультативних ознак суб'єктивної сторони складу злочину слід віднести його мету.

Під метою злочину слід розуміти вагомі, окреслені риси усвідомленого уявного образу майбутнього бажаного результату, який визначає направленість і упорядкованість різних дій, що спрямовані на вчинення злочину. 


\section{Список використаних джерел}

1. Харь I. O. Суб’єктивні ознаки і їх вплив на кваліфікацію діяння, вчиненого способом особливо жорстокого поводження // Науковий юридичний журнал. - 2013. - № 4. - С.104-112.

2. Павликівський B. I. Мета як обов'язкова ознака перешкоджання законній професійній діяльності журналістів // Науковий вісник Херсонського державного університету. Серія Юридичні науки. - Вип. 3. - Т. 3. - 2014. C. 80-84.

3. Мімук І. П. Кримінальне право. Загальна частина : навчально-методичний посіб. / І. П. Міщук. - К. : Інститут кримінально-виконавчої служби, 2014. - 106 с.

4. Касько Т. Ю. Ознаки суб'єктивної сторони ухилення від військової служби шляхом самокалічення або іншим способом // Юридичний науковий електронний журнал. - №3. - 2014. - С.112-114.

5. Bassionni M. Cherif. Substantive criminal law. - Springfield, 1978. - P. 177-181.

6. Parsons S. Intention in criminal law: why is it so difficult to find? // Mountbatten Journal Of Legal Studies. - 2004. P. 5-19.

7. Бабанли Р. Ш., Оніщук О. М. Суб'єктивні ознаки злочину, який полягає у зловживанні нотаріусом своїми повноваженнями (ст. 365-2 КК) // Часопис цивільного і кримінального судочинства. - 2013. - №. 2. - С. 118-127.

8. Семикіна Л. О. Суб'єктивна сторона вимагання // Свропейські перспективи. - 2013. - №. 4. - С. 112-118.

9. Вереша Р. В. Кримінальне право України. Загальна частина : навч. посіб., 2-ге вид., перероб. та доп. - К. : Центр учбової літератури, 2012. - 320 с.

10. Hart H. L. A. Intention and Punishment // Hart H. L. A. Punishment and Responsibility. Essays in the Philosophy of Law. Oxford : Clarendon Press, 1968. - P. 114-120.

11. Thomas Ch. W. and Bishop D. M. Criminal law. Understanding basic principles. Sage publications, 1987. - P. 50-56.

\section{References}

1. Har' I. O. Sub'€ktivni oznaki i ïh vpliv na kvalifikaciyu diyannya, vchinenogo sposobom osoblivo zhorstokogo povodzhennya // Naukovij yuridichnij zhurnal. - 2013. - № 4. - S.104-112.

2. Pavlikivs 'kij V. I. Meta yak obov'yazkova oznaka pereshkodzhannya zakonnij profesijnij diyal'nosti zhurnalistiv // Naukovij visnik Hersons'kogo derzhavnogo universitetu. Seriya Yuridichni nauki. Vipusk 3. Tom 3. 2014 S. 80-84.

3. Mishchuk I. P. Kriminal'ne pravo. Zagal'na chastina: navchal'no-metodichnij posibnik / I. P. Mishchuk. - K. : Institut kriminal'no-vikonavchoï sluzhbi, 2014. - $106 \mathrm{~s}$.

4. Kas 'ko T. Yu. Oznaki sub'ektivnoï storoni uhilennya vid vijs'kovoï sluzhbi shlyahom samokalichennya abo inshim sposobom // Yuridichnij naukovij elektronnij zhurnal. №3. 2014. S.112-114.

5. Bassionni M. Cherif. Substantive criminal law. - Springfield, 1978. P. 177-181.

6. Parsons $S$. Intention in criminal law: why is it so difficult to find? // Mountbatten Journal Of Legal Studies. 2004. R. 5-19.

7. Babanli R. Sh., Onishchuk O. M. Sub'ektivni oznaki zlochinu, yakij polyagaє u zlovzhivanni notariusom svoïmi povnovazhennyami (st. 365-2 KK) // Chasopis civil'nogo i kriminal'nogo sudochinstva. 2013. №. 2. S. 118-127.

8. Semikina L. O. Sub'ektivna storona vimagannya // Evropejs>ki perspektivi. 2013. №. 4. S. 112-118.

9. Veresha R. V. Kriminal'ne pravo Ukraïni. Zagal'na chastina. Navch. Posib. 2-ge vid. pererob. ta dop. K. : Centr uchbovoï literaturi, 2012. - $320 \mathrm{~s}$.

10. Nart H.L.A. Intention and Punishment// Nart H.L.A. Punishment and Responsibility. Essays in the Philosophy of Law. Ohford: Clarendon Press, 1968. R. 114-120.

11. Thomas Ch. W. and Bishop D.M. Criminal law. Understanding basic principles. Sage publications, 1987. R. 50-56.

\section{Вереша Р. В. Основні феноменологічні аспекти мети злочину}

У даній статті розглянуті проблеми кримінально-правової характеристики мети вчинення злочину. Проаналізовано характерні особливості мети вчинення злочину як ознаки суб'єктивної сторони злочину. Проведений аналіз дає можливість стверджувати, що в кримінальному праві зарубіжних держав спостерігається тенденція визначення мети злочину в переважній більшості не як обов'язкової ознаки злочинів. Обгрунтовано необхідність встановлення мети злочину, як однієї з ознак суб'єктивної сторони злочину, що дозволить виявити реальні причини злочину та застосувати правильний вид та розмір покарання. На основі проведеного дослідження автором встановлюється, що мета злочину є явищем психологічним, питання його аналізу та вивчення мають вирішуватись на пов'язаних 3 психологією та кримінологією рівнях, що матиме вплив на результати пізнання, отримані в межах однієї науки, на постановку пізнавальних завдань і уточнень елементів понять про свій предмет в іншій науці. Дається визначення мети вчинення злочину, під якою слід розуміти вагомі, окреслені риси усвідомленого уявного образу майбутнього бажаного результату, який визначає спрямованість і упорядкованість різних видів злочинної діяльності. На основі наукового підходу до теоретичного визначення мети в кримінальному праві і місця в суб'єктивній сто- 
роні складу злочину автором формується пропозиція, що під час дослідження злочину до факультативних ознак суб’єктивної сторони злочину слід відносити мету вчинення злочину.

Ключові слова: склад злочину, суб'єктивна сторона злочину, вина, мета злочину, мотив злочину, умисел, кваліфікація злочину, результат злочину.

\title{
Veresha R. V. The main phenomenological aspects of the criminal intent
}

This paper considers the problems of the criminal and legal characteristics of criminal intent. The author analyzed the peculiar features of criminal intent as an element of mens rea. The conducted analysis allows stating that the criminal law of certain countries displays a tendency of mostly recognizing criminal intent not as an obligatory element of crimes. The paper substantiates the need for recognizing criminal intent as one of the elements of mens rea, which will allow determining the real intent of the crime and administering the appropriate type and amount of penalty. The study determined that criminal intent is a psychological phenomenon. Therefore, the issues of its analysis and study should be solved at levels, related to psychology and criminology, which will affect the research results, obtained within the framework of one scientific branch, and the setting of research questions and elaboration of conceptual elements regarding this subject in other scientific branches. The paper defines criminal intent, which should be viewed as substantial and outlined features of a conscious imaginary image of the future desired result, which determines the orientation and ordering of various types of criminal activity. Based on a scientific approach to the theoretical determination of intent in criminal law and its place in the mens rea of corpus delicti, the author suggests relating criminal intent to the optional elements of mens rea.

The dialectic method provisions of scientific cognition of social and legal phenomena, its laws and categories lay the foundation for the methodology of the study of criminal and legal characteristics of criminal intent. The study successively applied such general scientific research methods as systems, historical, logical, functional, etc.

The criminal law of certain countries provides for an opportunity to determine the intent in certain types of intentional crimes. Determining criminal intent as an element of mens rea will allow determining the actual intent of crime and administering the appropriate type and amount of penalty.

Criminal intent should be viewed as substantial and outlined features of a conscious imaginary image of the future desired result, which determines the orientation and ordering of various actions, aimed at the commission of a crime. Since criminal intent affects the degree of the criminal act, the legislator can recognize it as a classifying element in certain corpora delicti. Criminal motive and criminal intent are different elements of mens rea, which require separate determination during crime investigation.

Key words: corpus delicti, mens rea, guilt, criminal intent, motive of crime, intention, classification of crime, crime result.

DOI: 10.33.66.3/2524-017X-2019-10-41-45

УДК 340

\author{
Тарас Олегович Дідич, \\ доиент кафедри теорії права та держави \\ юридичного факультету Київського національного \\ університету імені Тараса Шевченка
}

\section{МОНІТОРИНГ СУЧАСНОГО СТАНУ ПРАВОУТВОРЕННЯ В УКРАЇНІ: ПІЗНАВАЛЬНО-ПРАВОВІ АСПЕКТИ}

Постановка проблеми. Важливим елементом наукового дослідження є пізнавальні аспекти, що характеризують досліджуване явище чи процес як елемент реальності, відображаючи на темпоральному рівні його поточні, реально існуючі на момент пізнання, особливості. Їх вивчення дає змогу виявити та узагальнити сучасний стан розвитку досліджуваного явища чи процесу, здійснити їх критичний аналіз, з'ясувати наявні недоліки функціонування, виокремити перспективи розвитку, сформулювати і обгрунтувати шляхи їх удосконалення. Зазначений вектор наукового дослідження пов'язаний із встановленням та узагальненням особливостей досліджуваного явища чи процесу крізь призму їх сучасного стану розвитку, що можливо здійснити шляхом проведення відповідного моніторингу, як засобу пізнання. Це забезпечить можливість: по-перше, акумулювати результати теоретико-правових досліджень, узагальнити їх та встановити особливості доктринального розуміння стану розвитку досліджуваного явища; по-друге, екстраполювати результати теоре- 